\title{
ZAPIN AS RITUALIZED DHIKR: SILENT REMEMBRANCE OF GOD THROUGH MUSIC AND DANCE
}

\author{
Mohd Anis Md Nor \\ University of Malaya \\ (anisnor55@gmail.com)
}

\begin{abstract}
Almost all of the 240 million Muslims in Southeast Asia belong to the Sunni sect following the Shafii school of Muslim jurisprudence. They have practised Islam from the teachings of Muslim traders and preachers since the 12th century, which was further developed by Sufi mystics from the 13th century laying prominence on Islam's humanistic orientation, with emphasis on love and compassion. Accounting for about 42 percent of the total Southeast Asian population and 25 percent of the total world Muslim population (estimated at 1.6 billion), the three countries (Indonesia, Malaysia and Brunei) with Muslimmajority populations, and minority Muslims in Thailand, the Philippines, Singapore, Burma, Laos, Cambodia and Vietnam; have tolerated the meeting between monotheistic Islam, pantheistic tradition of Islamic mysticism and pre-Islamic traditions into a syncretized forbearance of Southeast Asian Islam (Yusof 2015). Islam not only spread through the expansion of trade among West Asia, India and Southeast Asia, but it also spread through Sufi missionaries who played a significant role in affirming the teaching is spreading the faith through the practices of the tariqah. Islam had a firm footing in maritime Southeast Asia by the time the Portuguese arrived in the $16^{\text {th }}$ century.
\end{abstract}

\section{Tariqah in Southeast Asia}

Sufism in Southeast Asia have produced rich literature from Sufi orders by well-known Sufi literary figures from such as Abu Hamid Muhammad AlGhazali, Ibn 'Arabi, Muhammad ibn Fadlullah al-Burhanpuri, Hamzah Fansuri, Syams ad-Din as-Sumatrani, Nur ad-Din ar-Raniri, Syaikh Yusuf alKhalwati, Muhammad ibn 'Abd al-Karim as-Samman al-Madani, and 'Abd asSamad al-Palimbani (Rahim, 1995: 5-7). Sufi orders or tariqah are used for both the social organisation and the special devotional exercises that are the basis of the order's ritual and structure (Voll, 1995: 109). Tariqah or Sufi orders in 
Southeast Asia gained ground through the tariqah or Tariqat Qadirriyyah, Syattariah, Kalwatiyyah Sammaniyyah and Kalidiyyah-Naqshabandiyah.

Almost all tariqah orders are named after its founder based on the chain or lineage of sheikhs known as the silsilah (Arabic: سلسلة). Except for the Naqshabandi order that goes back to the first Caliph Abu Bakr and the Prophet Muhammad, other silsilah leads back to the Prophet Muhammad through Ali, his cousin and son-in-law. The order is referred to the founder's name. For example, the tariqah and its silsilah of the "Rifai order" or "Rifaiyyah" is named after Sheikh Ahmad ar-Rafai while the silsilah of the "Qādirī order" is named after Sheikh 'Abd al-Qādir al-Jīlānī and the tariqah is referred to as the "Qādiriyyah".

Sufism is affirmed through the teaching of tariqah or way of the sharia't. The word sharia't literally means "the road to watering place" implying true knowledge. In the broadest sense, Sufism can be described as the interiorization and intensification of Islamic faith and practice. In general, Sufis have looked upon themselves as Muslims who take seriously God's call to perceive his presence both in the world and in the self. As such, they tend to stress inwardness over outwardness, contemplation over action, spiritual development over legalism, and cultivation of soul over social interaction (Chittick, 1995: 102). Tariqah (Arabic: طريقة Tarīqah; pl. turuq, or Turkish: tarikat) in Sufism is conceptually related to the ultimate truth or "haqiqah" that is sought by the aspirants (murìinn: singular murìd) of tarigah through the "guide" or murshid. A group of murìdin of a tariqah desires the knowledge of knowing God and loving God or faqir (Arabic: فقير), which they would refer to as "needing or desiring God's knowledge," or al-Faqīr ilá l-Lāh (Arabic: الفقير إلى الله ). Once a murid enters the tariqah, he gets his daily recitations, or 'awrād, which is authorised by his murshid. The 'awräd or recitation is usually recited before or after prayers (pre-dawn, afternoon and evening prayers) and may consist of reciting a certain formula for tens, hundreds or a thousand times.

Sufi orders or tariqah engage in ritualized dhikr (Arabic: ذككار is plural adhakār, which means remembrance, pronouncement or invocation of the names of God). In Southeast Asia, dhikr is considered an important extension to the recitation of doa (ordinary supplication to ask for divine blessing in general). Dhikr, the devotional acts in Islam in which short phrases or prayers are repeatedly recited silently within the heart or aloud, takes the form of methodological repetition of the first shahadah (proclamation of one's belief in Allah and his messenger, Muhammad) or the names of God or God's "most beautiful names" (al-asma' al-husna) or some formula such as "Allah hayy" (God is the Eternal one) with prescribed gestures, has become one of the 
fundamental rituals in tariqah or tariqat. A gathering to perform the Dhikr ritual usually takes place in private homes or closed public spaces. Such gatherings could be convened with the presence of a culturally structured movement system and musical accompaniment (Mohd Anis Md Nor, 2009: 35).

The devotional act of repeating the names of God or of God's "most beautiful names" (al-asma' al-husna) in dhikr or supplications or formulas are taken from hadith texts and verses of the Qur'an is usually done individually. But in some Sufi orders dhikr is instituted as a ceremonial activity, which may be ritually determined by the sheikh for his murids. Followers of Sufism engage in ritualized dhikr by each order or lineage (silsilah), which may include recitation, singing, instrumental music, dance, and ecstasy.

However, Sufi practices that are embedded in the performing arts of Southeast Asia are rarely known outside its circle of practitioners and has remained as an esoteric knowledge of the beholder. To an outsider, Sufi music or dance performances continue to be seen as conventional performances of folk traditions, performed for celebratory occasions or staged as public spectacle rather than a religious one. Dhikr as a solemn form of supplication plays an important role in negotiating temporality in the zapin dance in maritime Southeast Asia, connecting the Malay world and the world of the Southern Arabian Peninsula.

\section{Zapin as ritualized Dhikr}

Ritualized dhikr in the form of a corporeal act of remembrance, pronouncement or invocation of the names of God could be observed exclusively in the zapin, which is known by various other names such as jipin, jepin, japin, zafin and dana in Malaysia, Indonesia, Southern Thailand, Brunei and Singapore. Indigenous Southeast Asians created zapin as a hybrid form through syncretic borrowing and adapting of the Arabic zaffin from Hadramaut in the southern part of the Arabian Peninsula. Both zapin and zaffin are dominated by men, with an exception of the Malay zapin which allows women's participation since the 1970s (Mohd Anis Md Nor 2011: 42-43).

Malay zapin has extrinsic and intrinsic qualities, the former celebrates events associated with weddings, circumcisions, and social events of religious significance such as Maulidur Rasul (Prophet's birthday), and the latter is associated with ritualized dhikr. It had taken roots amongst the Malay-Islamic communities in the Straits of Malacca to become one of the most widely spread ritualized dhikr performed overtly or covertly in insular Southeast Asia. 
Extrinsic relationships are driven by contextual cues and prior knowledge of the performance traditions whilst intrinsic relationships are derived from structures and elements of performance (Mason, 2012: 18), in this context, the invocation dhikr is embedded in music and movement of zapin. Although they are holistically interrelated, ritualized dhikr is intrinsically contingent on the performers' ability to gaze the dhikr gestural-rhythm mimetic qualities while dancing the zapin relies on the extrinsic correlation of melodic-harmonicrhythmic musical sounds in their step-motifs in time and space. Dancing/musicking and dikhr mutually coalesced cadences and segmentations shaped the interdependent relationship of music and body movements, and evoked a sense of ritualized dhikr through musicking and performing culturally structured movement system. The zenith of interactive dancing/musicking and silent remembrance or invocation of the name of God in ritualized dhikr is reached through artistic choices and self-reflexive approaches to creating music and dance as holistic dhikr rather than of separate entities. Whilst body movements occupy a singular visual position in zapin performance, ritualized dhikr manipulate movements and sound in a singular cohesive entity that are intrinsically and extrinsically satisfying to the zapin beholders. The overlapping combination of music-movement and ritualized dhikr are mutually negotiated through the gazes of the musicians and dancers, sensing kinesthetic pulses within the temporal units of the cyclical pattern of sound within the metric iso-periodic zapin tune/music.

Dhikr recitation has been observed in the Arabic zaffin and Malay zapin by practitioners or muridin of tarigah al-Alawiyah or otherwise known as the Ba-'Alawi in the former, and the tariqah Naqshabandiyah, in the latter. The members of Ba'Alawi tarigah are mainly Sayyid or Syed (سيد) whose ancestors hail from the Valley of Hadhramaut, are held in high esteem as descendants of the Prophet Muhammad (Othman, 1998: Azra, 2004), while members of the tariqah Naqsabandiyah are exclusively Malay and Indonesian.

Although the muridin of tariqah al-Alawiyah or Ba'Alawi remains exclusively within the descendants of Sayyid or Syed (سيد) from Hadhramaut in Southeast Asia, similar practices could be observed in the practices of the Malay zapin, introverted as silent dhikr by the muridin of tariqah Naqshabandiyah. The inclusion of a structured movement system and music as a means of convening silent dhikr amongst Naqshabandis in Southeast Asia is exclusive to practitioners of zapin. However, not all zapin performers are dhikr practitioners, and zapin does not implicitly signify dhikr. Ritualized dhikr in zapin is exclusive to the muridin of Naqshabandiyah or tarigah KhalidiyyahNaqshabandiyah. 
The corpus of ritualized dhikr in zapin is in the affirmation of tawhid, the essence of Islam that affirms Allah (SWT) to be the One, the absolute, transcendent Creator, the Lord and Master. The notion of tawhid is derived from "one," "unique" (wahid) that is translated as in the unity of God, oneness, peerlessness, and utter transcendence of God. Islam declares the transcendence of God to be part and parcel of Islamic philosophy, of life and of the believers' way of asserting that God has created all humans capable of knowing Him in His transcendence (Mohd Anis Md Nor, 2003).

\section{Zapin as Corporeal Dhikr}

Zapin music and dance are conventionally structured into three parts. The first part is marked by a taksim, an improvised solo played by a single 'ud or locally known as the gambus (lute). The gambus is derived from the Middle Eastern ' $u d$, a pear-shaped chordophone with rounded wooden back and short fretless neck. It has five to eight strings in double courses and a single string that are plucked with fingers. The second part consist of a melodic section with kopak, a loud rhythmic marwas drumming patterns in interlocking style, while the final section is known as the wainab or tahtim, which forms the coda for a piece to end that utilizes an extension of the main melodic phrase and the loud kopak drumming pattern (Mohd Anis Md Nor, 2004: 128-130). The divisional units or sections in the zapin music have become generic in areas along the Straits of Malacca.

The musical sections of zapin music correspond with the sections of the dance performance. All zapin performers are required to enter the dance area in a single file or in double rows and present a salutation to the musical prelude or Taksim, played by a single 'ud or gambus (lute) player. This is to be followed by the linear formation of zapin performers who dance facing one another while repeating dance motifs while tracing a recurring forward and backwards floor plan, interrupted by a series of skips and squatting positions, which is also known as the kopak. At the end of each performance, the dancers perform jumping and squatting dance motifs to the accompaniment of relatively faster drumbeats in the form of the wainab (Mohd Anis Md Nor, 2009: 37).

Dancing the zapin or playing zapin music could become corporeal dikhr only if the practitioner wishes to embody the body movements or musical pulses as pulses of the silent dhikr utterance. The litanies of $d h i k r$ are not heard beyond introvert individual recitations. It is performed as a silent dhikr while the zapin songs or qasidah are sung by one of two singers. The dancers' 4-beat 
pattern from the pulses of their dhikr litanies frames the basic dance unit, which is accompanied by the musical sounds of the instruments such as the marwas hand drums and the dok barrel drum. A repetitive rhythmic 4-beat pattern of three or more marwas hand drums punctuated by a dok drum over a 16-beat unit frames the dance motifs.

The compound structure of zapin drumming patterns within a 16-beat metric iso-periodic unit and the overarching rendition of zapin songs or qasidah consisting of repeated quatrains of passionate verses in praise of Prophet Muhammad and the attributes of God either literally or metaphorically provides the spatial and sonic space for dhikr. Although dance movements only begin on the second drum beat, which is of low timbre as it initiates the kinemic pulse, dhikr is first uttered during the first high timbre beat of the marwas drums. The first shahadah, Lā ilaha illal-Lāh, Muhammadun rasūlula-Lāh ("There is no god but God, Muhammad is the Messenger of God") commences on the high timber beat while the dance begins on the low timbre beat, which forms the second drum beat. The entire zhikr would be completed at the end of the 8-beat phrase of a repetitive rhythmic 4-beat pattern of three or more marwas drums. By then, the dhikr-dancer completes his dance motif as he completes the first round of his shahadah. The dhikr would be repeated over the 8-beat phrase into the second round of shahadah recitation as the dancers complete his dance or choreme over 16-beats unit.

Within these chronological grammatical choreographic units, the zapin dancers interact with drummers and other zapin musicians with mnemonic vocalisations while sustaining the silent dhikr over improvised dance motifs. To practitioners of Tariqat Naqshabandiyah, most of the improvisations that deal with syncopated dance movements within an iso-periodic unit of zapin music provide both spatial and sonic space for the inward contemplation of God's oneness and peerlessness, the spiritual essence of Tawhid. To nonpractitioners of Tariqat Naqshabandiyah, the extrinsic movement improvisations within the iso-periodic unit of zapin music with mnemonic vocalisations are deliberately made to impress or challenge new dancers or to encourage others to join in the dance or as signals to the musicians to end their performance. Zapin ends with a loud rhythmic kopak played by interlocking drumming patterns of the marwas hand drums. In this final section known as the wainab or tahtim, the intrinsic qualities of zapin reached its climax. The word 'wainab' is derived from the Arabic word wainaq (وعانق), which means embraced or hug (وغناق). The word wainaq (وعانق) appears to signify the climatic yearning of wanting to be embraced by God or embracing God. Zapin reinforces the pinnacle state of the temporality of the silent dhikr. It is a 
knowledge of the esoteric, known and understood by those whose tariqah commands the murìinn to embrace God's call to perceive his presence both in the world and in the self, best described as a Sufistic path.

\section{Tolerance: Corporeal Dhikr}

Corporeal dhikr within zapin embodies intrinsic mental or verbal repetition of one of the divine names of God over the extrinsic regular 4-beat counts of the drumming pattern. The ritualized $d h i k r$ executed through repetitive steps of zapin dance motifs affirms the way of the sharia't, implying knowledge and teaching of the tariqah. The muridin of tariqah Naqshabandiyah in Southeast Asia, negotiates temporality in zapin through dhikr's utterance of God's name and/or methodological repetition of the first shahadah (proclamation of one's belief in Allah and in his messenger, Muhammad) through ritualized dhikr, which stresses inwardness of contemplating God's existence and in his absolute transcendence, hence affirming the ultimate truth or "haqiqah" fundamental to mystical Islam.

Zapin as ritualized dhikr is generally tolerated by the Muslim ummah (nation or community) in Southeast Asia because zapin is foremost a secular structured movement system. Zapin becomes mystical when dhikr is ritually performed with the extrinsic and intrinsic qualities of corporeal dhikr by the murìin of tariqah Naqshabandiyah, either covertly within the close circle of murìin or overtly amongst dhikr practitioners. However, in recent time ritualized dhikr in zapin is being contested by the resurgence of the Salafiyah influence by nascent Wahhabis in Southeast Asia. The Salafi or Salafist movement is an ultra-conservative movement within Sunni Islam that references the doctrine known as Salafism with a fundamentalist approach to Islam often described as being synonymous with Wahhabism. Wahhabism is a religious movement of Sunni Islam, orthodox and puritanical, from the teachings of eighteenth-century preacher and scholar, Muhammad ibn Abd alWahhab (1703-1792) in Saudi Arabia. The Salafists abhorred ritualized dhikr as being religious innovation, or bida (heretical doctrine or heresy).

The emergence of Salafists doctrine through the processes of "culturalArabization" by Southeast Asian Wahabi adherents within the last two decades in Southeast Asian have greatly influenced Southeast Asian Muslims to condemn common practices such as ritualized dhikr as polytheism or shirk, reduced the visibility of ritualized dhikr in zapin amongst the Southeast Asian Muslims. It has not only impacted the overt display of ritualized dhikr in zapin but in all forms of corporeal practices. However, in recent time, fear for the 
demise of indigenous Islamic cultural practices through the unabridged processes of cultural-Arabization have encouraged Muslim politicians and Southeast Asian ulama (Muslim legal scholars) to counter such advances through "political" and "spiritual" voices. These voices amongst others affirmatively supported dhikr within a structured movement system, such as zapin, as tolerable (mubah) in Islam.

During the opening of the National Conference of Ulema Board of Nahdlatul Ulama at the Istiqlal Mosque in Jakarta in Jun 2015, President Joko Widodo or Jokowi of Indonesia introduced the term "Islam Nusantara" as a retort to the Arabization and Neo Talibanisation of Indonesian Muslims. In an interview with the BBC Indonesia after the event, Jokowi affirmed that "Islam Nusantara is a friendly Islam, not radical, inclusive and tolerant." The Indonesian President emphasised that "Islam in the Indonesian archipelago was spread over the ages by a cultural approach that is not rigid and hard, and thus Indonesian Muslims should not become Arabized but to keep to the indigenous practices of Islam" (Amin Iskandar 2015).

Haron Din, an ulama and the spiritual leader of the Pan-Malaysia Islamic Party, riposted a verse from the Holy Quran to refute the condemnations of ritualized corporeal zhikr amongst tariqa orders by Southeast Asia Salafists. The verse from Sura Al-Imran in the third chapter of the Qur'an affirms the tolerance of corporeal dhikr.

"Who remember Allah [Dhikr] while standing or sitting or [lying] on their sides and give thought to the creation of the heavens and the earth, [saying], "Our Lord, You did not create this aimlessly; exalted are You [above such a thing]; then protect us from the punishment of the Fire."'(Surah Ali Imran verse 191)

The Ulama argues that corporeal dhikr is not haram (forbidden) in Islam as long as men and women do it separately and when the body movements and gestures are innately connected to remember and proclaim the shahadah (proclamation of one's belief in Allah and his messenger, Muhammad), which stresses an inwardness of contemplating God's existence and his absolute transcendence.

The affirmation to sustain the roots and traditions of Southeast Asian Islam (Islam Nusantara) by President Jokowi of Indonesia and barrages of counter statements by Muslim legal scholars to admonish Salafists doctrine in Malaysia and Indonesia have enabled zapin to continue to draw practitioners towards ritualized dhikr where music and dance negotiate religious and 
cultural practices. Zapin as ritualized dhikr has stood against these biases to remain significant to indigenous Southeast Asian Muslims contesting a recent import of ultra-conservative Wahhabism from the Middle East. Southeast Asian ulama (Muslim legal scholars) affirmatively supported dhikr (recitation of the divine names or litanies) within a structured movement system as tolerable (mubah) in Islam. This resonates well with existing practices observed in the zapin dance and music in the coastal areas of maritime Southeast Asia performed by followers of tariqah. Corporeal dhikr symbolises the broad way in which the performer-practitioners find a way to travel and seek God.

\section{Endnotes}

"Taksim is derived from the Arabic word "taqsim," which means "division" or "distribution" and refers to a special improvisational musical form that is guided by the Makam system, a system of melody types, which provides a set of rules for composition.

\section{References}

Algar, Hamid. (1995). "Naqshbandiyah," in Esposito, John L. (editor) The Oxford Encyclopedia of the Modern Islamic World, Vol. 4, New York: Oxford University Press, 226-229.

Amin Iskandar. (2015). http://www.themalaysianinsider.com/opinion/aminiskandar/article/apabila-budaya-melayu-ditelan-budaya-arab1 retrieved 6 July 2015

Azra, Azyumardi. (2004). The Origins of Islamic Reformism in Southeast Asia: Networks of Malay-Indonesian and Middle Eastern "Ulama" in the seventeenth and eighteenth centuries. Honolulu: Allen \& Unwin.

Chittick, William C. (1995). "Sufism: Sufi though and practice," in Esposito, John L. (editor) The Oxford Encyclopedia of the Modern Islamic World, Vol. 4, New York: Oxford University Press, 102-109.

Haron Din. (2014). http://www.harakahdaily.my/pandangan-haron-dinberkenaan-zikir-sambil-menari retrieved Jan 20, 2014.

Mason, Paul H. (2012). "Music, dance and the total art work: Choreomusicology in theory and practice," Research in Dance Education, $13: 1,5-24$.

2011. "Modes of transmissions: Traditional West Sumatran \& contemporary West Javanese practices of indigenous martial arts," in Hybridity in the 
Performing Arts of Southeast Asia. Proceedings of the $1^{\text {st }}$ Symposium of the ICTM Study group on Performing Arts of Southeast Asia. Mohd. Anis Md. Nor, et al., ed., Kuala Lumpur: Nusantara Performing Arts Research Centre \& Department of the Southeast Asian Studies University of Malaya, 113-119.

Mohd Anis Md Nor. (1993). Zapin: folk dance of the Malay world. Singapore: Oxford University Press.

2002. "Reinventing tradition in the context of public vs. private displays of dance in Sabah and Sarawak," paper read at the Borneo Research Council $7^{\text {th }}$ Biennial International Conference. Sabah, Universiti Malaysia Sabah, July 15-18.

2003. "Iconographic perspectives of Islamic culture and their dances," paper read at the Dance Iconography Sub-Study Group Meeting of the ICTM Study Group on Ethnochoreology. Bamberg, Germany, March 27-30.

2004. "The relationship of traditional Malaysian dance movements to the colotomic units of music," paper read at the 37th ICTM World Conference in Fuzhou and Quanzhou, China, January 4-11.

2009. "The spiritual essence of tawhid (oneness-peerlessness) in zapin dance performance by the beholders of the Tariqat Naqsabandiah in Southeast Asia," in JATI: Journal of Southeast Asian Studies. Faculty of Arts and Social Sciences, University of Malaya, Vol.14, December, 33-39.

Mohd Anis Md Nor and Stephanie Burridge (ed.). (2011). Sharing Identities: Celebrating dance in Malaysia. New Delhi: Routledge.

Mohammad Redzuan Othman. (1998). The role of Makka-educated Malays in the development of early Islamic scholarship and education in Malaya, Journal of Islamic Studies 9(2): 146-157.

Rahim, Yunus. (1995). "Posisi tasauf dalam sistem kekuasaan di kesultanan Buton pada abad ke-19", Jakarta: NKIS.

Ricklefs, M. C. (2006). Mystic synthesis in Java: A history of Islamization from the fourteenth to the early nineteenth centuries. Norwalk, CT: EastBridge.

Voll, John O. (1995). "Sufism: Sufi orders," in Esposito, John L. (editor) The Oxford Encyclopedia of the Modern Islamic World, Vol.4, New York: Oxford University Press, 109-116.

Yusof, Imtiyaz. (2015). The Middle East and Muslim Southeast Asia: Implications of the Arab Spring. Oxford: Oxford Centre for Islamic Studies http://www.oxfordislamicstudies.com/Public/focus/essay1009_southeast _asia.html retrieved 5 July 2015.

https://www.youtube.com/watch?v=ChZTWdtn-PY 